\title{
EMERGENCE, GROWTH AND PRODUCTION OF SESAME UNDER SALT STRESS AND PROPORTIONS OF NITRATE AND AMMONIUM ${ }^{1}$
}

\author{
ADAAN SUDARIO DIAS ${ }^{2}$, GEOVANI SOARES DE LIMA ${ }^{2 *}$, HANS RAJ GHEYI ${ }^{3}$, REGINALDO GOMES NOBRE ${ }^{4}$, \\ JOÃO BATISTA DOS SANTOS ${ }^{4}$
}

\begin{abstract}
In arid and semi-arid regions, the quality of irrigation water varies in geographic terms and during the year, and the occurrence of water with high concentrations of salts is common. In this context, this study aimed to evaluate the emergence, growth and production of sesame, cultivar CNPA G3, irrigated with saline water and fertilized with $\mathrm{N}$ of different carrier proportions by the ratio of nitrate and ammonium $\left(\mathrm{NO}_{3}^{-}-\mathrm{N}\right.$ and $\mathrm{NH}_{4}{ }^{+} \mathrm{-N}$ ) in an experiment conducted in lysimeters arranged in a greenhouse in the municipality of Campina Grande-PB, Brazil. The treatments were distributed into randomized blocks using a $5 \times 5$ factorial scheme relative to levels of irrigation water salinity (ECw; $0.6,1.2,1.8,2.4$ and $3.0 \mathrm{dS} \mathrm{m}^{-1}$ ) and five proportions of $\mathrm{NO}_{3}{ }^{-}-\mathrm{N}^{-} \mathrm{NH}_{4}{ }^{+}-\mathrm{N}$ $\left(200 / 0 ; 150 / 50 ; 100 / 100 ; 50 / 150\right.$ and $0 / 200 \mathrm{mg}$ of $\left.\mathrm{N} \mathrm{kg}^{-1}\right)$, with three replicates. The increase in ECw compromised the emergence, growth and production of sesame, cultivar CNPA G3, and the production components were the most sensitive variables. The highest growth in diameter was obtained with the proportion of $200 / 0 \mathrm{mg} \mathrm{kg}^{-1}$ of $\mathrm{NO}_{3}{ }^{-} \mathrm{N} / \mathrm{NH}_{4}{ }^{+}-\mathrm{N}$. An ECw level of $3.0 \mathrm{dS} \mathrm{m}{ }^{-1}$ and fertilization with $0 / 200 \mathrm{mg} \mathrm{kg}{ }^{-1}$ of $\mathrm{NO}_{3}{ }^{-}-\mathrm{N}^{-} \mathrm{NH}_{4}{ }^{+}-\mathrm{N}$ promoted deleterious effects on the total mass of sesame fruits and mass of seeds. The interaction between water salinity levels and $\mathrm{NO}_{3}{ }^{-} / \mathrm{NH}_{4}{ }^{+}$proportions significantly affected the number of leaves (at 50 and 70 days after sowing), the total mass of fruits and the mass of seeds.
\end{abstract}

Keywords: Sesamum indicum L.. Water quality. Nitrogen.

\section{EMERGÊNCIA, CRESCIMENTO E PRODUÇ̃̃O DE GERGELIM SOB ESTRESSE SALINO E PROPORÇÕES DE NITRATO E AMÔNIO}

RESUMO - Nas regiões áridas e semiáridas a qualidade da água usada na irrigação varia em termos geográficos e ao longo do ano, sendo comum a ocorrência de águas com elevada concentração de sais. Neste contexto, objetivou-se com este trabalho avaliar a emergência, crescimento e a produção do gergelim cv. CNPA G3 irrigado com águas salinas e adubado com proporções de $\mathrm{N}$ pela relação nitrato e amônio $\left(\mathrm{N}^{-} \mathrm{NO}_{3}{ }^{-} \mathrm{e}\right.$ $\mathrm{N}^{-\mathrm{NH}_{4}}{ }_{4}{ }$ ) em ensaio conduzido em lisímetros dispostos em casa de vegetação no município de Campina Grande, $\mathrm{PB}$. Os tratamentos foram distribuídos em blocos ao acaso usando o esquema fatorial 5 x 5 relativos aos valores de condutividade elétrica da água de irrigação - $\mathrm{CEa}\left(0,6 ; 1,2 ; 1,8 ; 2,4\right.$ e $\left.3,0 \mathrm{dS} \mathrm{m}^{-1}\right)$ e cinco proporções de $\mathrm{NO}_{3}{ }_{3}^{-} \mathrm{N} /$ $\mathrm{NH}_{4}{ }^{+} \mathrm{N}\left(200 / 0 ; 150 / 50 ; 100 / 100 ; 50 / 150 ; 0 / 200 \mathrm{mg}\right.$ de $\left.\mathrm{N} \mathrm{kg}^{-1}\right)$, com três repetições. O aumento da CEa comprometeu a emergência, o crescimento e a produção do gergelim cv CNPA G3, sendo os componentes de produção as variáveis mais sensíveis. O maior crescimento em diâmetro do caule foi obtido com proporção de 200/0 mg kg ${ }^{-1}$ de $\mathrm{NO}_{3}{ }^{-}-\mathrm{N} / \mathrm{NH}_{4}{ }^{+}-\mathrm{N}$. Nível de $\mathrm{CEa}$ de $3,0 \mathrm{dS} \mathrm{m}^{-1}$ e adubação com $0 / 200 \mathrm{mg} \mathrm{kg}^{-1} \mathrm{de} \mathrm{NO}_{3}^{-}{ }^{-} \mathrm{N} / \mathrm{NH}_{4}{ }^{+}-$ $\mathrm{N}$ promoveram efeito deletério sobre a massa total de frutos e na massa de sementes do gergelim. A interação entre os níveis salinos das águas e as proporções de nitrato e amônio afetou significativamente o número de folhas (aos 50 e 70 dias após a semeadura), a massa total de frutos e a massa de sementes.

Palavras-chave: Sesamum indicum L.. Qualidade de água. Nitrogênio.

\footnotetext{
*Corresponding author

${ }^{1}$ Received for publication in $05 / 16 / 2016$; accepted in 10/18/2016.

Part of the Masters Dissertation in Agricultural Engineering of the first author

${ }^{2}$ Center of Technology and Natural Resources, Universidade Federal de Campina Grande, Campina Grande, PB, Brazil; sudario_dias@hotmail.com, geovanisoareslima@gmail.com.

${ }^{3}$ Nucleus of Soil and Water Engineering, Universidade Federal do Recôncavo da Bahia, Cruz das Almas, BA, Brazil; hans@pq.cnpq.br.

${ }^{4}$ Center of Agrifood Science and Technology, Universidade Federal de Campina Grande, Pombal, PB, Brazil; rgomesnobre@yahoo.com.br, agrosantos@hotmail.com.
} 


\section{INTRODUCTION}

Sesame (Sesamum indicum L.) belongs to the Pedaliaceae family, and Africa is considered its center of origin due to the large number of species from the Sesamum genus on that continent (SOUSA et al., 2014). The oil extracted from its seeds can be used in the manufacturing of pies, margarine, perfumes, lubricants, medicines and soap. In addition, the high content of unsaturated fatty acids in the oil and digestive protein in the grains make sesame a food of high quality for human and non-ruminant domestic animals (AMABILE et al., 2001).

Besides the nutritional importance, sesame stands out in terms of good production stability relative to the water factor (low water requirement) compared to other cultivated species and constitutes an alternative source of income, especially for small and medium farmers in northeastern Brazil (ARAÚJO et al., 2014).

In this region, the occurrence of high temperatures, low rainfall, irregular rainfall distribution and intense evaporation is common. Combined with the variability in the water quality used for irrigation, in both spatial and temporal terms, the occurrence of water with high concentration of salts is common (ALVES et al., 2011). The use of water with high concentrations of salts limits the growth and production of vegetables, due to the reduction in the osmotic potential of the soil solution, and also may cause ionic toxicity, nutritional imbalances or both (FLOWERS, 2004).

Various studies have indicated the sesame crop to be sensitive to salinity (RHOADES; KANDIAH; MASHALI, 2000; SUASSUNA, 2013); however, there are reports pointing to it being moderately tolerant to salt stress (ABBASDOKHT et al., 2012; BAHRAMI; RAZMJOO, 2012). Therefore, it is evident that the use of saline water for irrigation is conditioned to the tolerance of crops to salinity and to the practices of both irrigation and fertilization management (LIMA et al., 2015); the tolerance level of plants to salinity may vary depending on the species and cultivars of the same species in addition to other factors, such as both type and concentration of salt as well as exposure time (GARCIA et al., 2010).

Among the management practices that can reduce the deleterious effects caused by salinity stress on sesame crops, $\mathrm{N}$ fertilization stands out (LIMA et al., 2012). In the soil solution, $\mathrm{N}$ can be found in the nitric and ammoniacal forms, but the rates of absorption by higher plants are influenced by factors such as the $\mathrm{NO}_{3}{ }^{-} / \mathrm{NH}_{4}{ }^{+}$proportion in the environment, temperature and concentration of carbohydrates in the roots, among others (TAIZ; ZEIGER, 2013). In addition, the interaction between $\mathrm{N}$ sources (nitric and ammoniacal) in plants has different effects on their growth and development
(MASCLAUX- DAUBRESSE et al., 2010).

According to Ali, Sivakami and Raghuram (2007), the supply of $\mathrm{N}$ exclusively as $\mathrm{NO}_{3}^{-}$may result in a decrease in dry matter production in plants with low capacity to reduce $\mathrm{NO}_{3}{ }^{-}$, because, for the $\mathrm{N}$ to perform its functions in the plant, it is necessary that it be reduced and incorporated into organic compounds. On the other hand, high levels of $\mathrm{NH}_{4}{ }^{+}$ in the tissue cells can be toxic and cause negative effects on root and shoot growth (HACHIYA et al., 2012), leading to physiological and nutritional disorders (HOLZSCHUH et al., 2011).

Thus, this study aimed to evaluate the emergence, growth and production of sesame, cultivar CNPA G3, irrigated with saline water and fertilized with different proportions of $\mathrm{NO}_{3}{ }^{-}$and $\mathrm{NH}_{4}^{+}$.

\section{MATERIAL AND METHODS}

The research was conducted in recipients adapted as lysimeters under greenhouse conditions at the Center of Technology and Natural Resources of the Federal University of Campina Grande, Campina Grande-PB, Brazil, situated at the local geographic coordinates $7^{\circ} 15^{\prime} 18^{\prime}$ 'S, $35^{\circ} 52^{\prime} 28^{\prime \prime} \mathrm{W}$ at a mean altitude of $550 \mathrm{~m}$.

The experimental design consisted of randomized blocks in a $5 \times 5$ factorial scheme, with three replicates, totaling 75 experimental units, in which the treatments resulted from the combination of five levels of irrigation water electrical conductivity (ECw; 0.6, 1.2, 1.8, 2.4 and $3.0 \mathrm{dS} \mathrm{m}^{-1}$ ), associated with five proportions of $\mathrm{NO}_{3}{ }^{-} \mathrm{N}$ and $\mathrm{NH}_{4}{ }^{+}$ -N (200:0, 150:50, 100:100, 50:150 and 0:200 $\mathrm{mg} \mathrm{N} \mathrm{kg}^{-1}$ of soil).

The salinity levels (SL) of the water used in the irrigation of the sesame cultivar CNPA G3 were prepared in order to obtain a proportion equivalent to $7: 2: 1$ of $\mathrm{Na}^{+}: \mathrm{Ca}^{2+}: \mathrm{Mg}^{2+}$, respectively, using the salts $\mathrm{NaCl}, \mathrm{CaCl}_{2} \cdot 2 \mathrm{H}_{2} \mathrm{O}$ and $\mathrm{MgCl}_{2} \cdot 6 \mathrm{H}_{2} \mathrm{O}$, adjusting them to the electrical conductivity values of the public-supply water available in the municipality of Campina Grande-PB $\left(\mathrm{ECw}=1.35 \mathrm{dS} \mathrm{m}^{-1}\right)$. The levels of 0.6 and $1.2 \mathrm{dS} \mathrm{m}^{-1}$ were obtained from a mixture of public-supply water and the rainwater $\left(\mathrm{ECw}=0.02 \mathrm{dSm}^{-1}\right)$. After preparation and $\mathrm{ECW}$ calibration, the solutions were stored in 200 -L plastic containers that were properly protected to avoid evaporation and entry of small insects as well as the entry and/or contamination with materials that could compromise the quality.

Plants were cultivated in lysimeters with a capacity of $20 \mathrm{~L}$, with a hole at the bottom to allow drainage, connected to a transparent drain with diameter of $4 \mathrm{~mm}$. The tip of the drain inside the lysimeter was fitted with a nonwoven geotextile (Bidim OP 30) to avoid clogging with soil material. The other tip of each drain was connected to a plastic 
bottle to collect the drained water and for estimating water consumed by the plants. The lysimeters were filled with a layer of $0.5 \mathrm{~kg}$ of crushed stone, followed by $24.5 \mathrm{~kg}$ of eutrophic Regolithic Neosol, of a sandy loam texture $(0-20 \mathrm{~cm})$, from the rural area of the municipality of Esperança-PB, properly crushed to break up clods, whose chemical and physical attributes (Table 1) were determined using the methodologies proposed by Donagema et al. (2011).

Table 1. Chemical and physical attributes* of the soil used in the experiment, prior to applying treatments.

\begin{tabular}{|c|c|c|c|c|c|c|c|c|c|}
\hline \multicolumn{10}{|c|}{ Chemical characteristics } \\
\hline \multirow{2}{*}{$\begin{array}{c}\mathrm{pH}\left(\mathrm{H}_{2} \mathrm{O}\right) \\
(1: 2.5)\end{array}$} & \multirow{2}{*}{$\begin{array}{c}\mathrm{OM} \\
\text { dag kg-1 }\end{array}$} & \multirow{2}{*}{$\begin{array}{c}\mathrm{P} \\
\left(\mathrm{mg} \mathrm{kg}^{-1}\right)\end{array}$} & $\mathrm{K}^{+}$ & $\mathrm{Na}^{+}$ & $\mathrm{Ca}^{2+}$ & $\mathrm{Mg}^{2+}$ & $\mathrm{H}^{+}+\mathrm{Al}^{3+}$ & \multirow{2}{*}{$\begin{array}{l}\text { ESP } \\
(\%)\end{array}$} & \multirow{2}{*}{$\begin{array}{c}\text { ECse } \\
\left(\mathrm{dS} \mathrm{m}^{-1}\right)\end{array}$} \\
\hline & & & \multicolumn{5}{|c|}{ 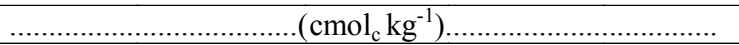 } & & \\
\hline 6.24 & 10.79 & 48.00 & 0.28 & 1.82 & 7.41 & 5.23 & 3.07 & 11.38 & 2.50 \\
\hline \multicolumn{10}{|c|}{ Physical characteristics } \\
\hline \multicolumn{3}{|c|}{ Size fraction $\left(\mathrm{g} \mathrm{kg}^{-1}\right)$} & \multirow{2}{*}{$\begin{array}{c}\text { Textural } \\
\text { Class }\end{array}$} & \multicolumn{2}{|c|}{ Water content $(\mathrm{kPa})$} & \multirow[t]{2}{*}{$\mathrm{AW}$} & \multirow{2}{*}{$\begin{array}{c}\text { Total } \\
\text { porosity } \\
\mathrm{m}^{3} \mathrm{~m}^{-3}\end{array}$} & \multirow{2}{*}{$\begin{array}{c}\mathrm{AD} \\
\left(\mathrm{kg} \mathrm{dm}^{-3}\right)\end{array}$} & \multirow{2}{*}{ PD } \\
\hline Sand & Silt & Clay & & $\begin{array}{l}33.42 \\
\ldots \ldots \ldots \ldots \ldots . . . .\end{array}$ & $\begin{array}{l}1519.5 \\
\text { dag kg-1 }\end{array}$ & & & & \\
\hline 656.6 & 175.0 & 168.4 & SL & 28.84 & 10.42 & 18.42 & 0.53 & 1.27 & 2.74 \\
\hline
\end{tabular}

"Determined using the methodologies proposed by Donagema et al. (2011).

$\mathrm{OM}$ - Organic matter: Walkley-Black wet digestion; $\mathrm{Ca}^{2+}$ and $\mathrm{Mg}^{2+}$ extracted with $1 \mathrm{M} \mathrm{KCl}, \mathrm{pH} 7.0$; $\mathrm{Na}^{+}$and $\mathrm{K}^{+}$ extracted with $1 \mathrm{M} \mathrm{NH}_{4} \mathrm{OAc}$, pH 7.0; ESP- Exchangeable sodium percentage; ECse - Electrical conductivity of the saturation extract; SL - Sandy loam; AW - Available water; AD - Apparent density; PD - Particle density.

The experiment used the sesame cultivar CNPA G3, which has medium size; a cycle between 90 and 100 days; a branched growth habit; and uniform flowering and maturation. It has one fruit/ axil and cream-colored seeds. It has resistance to angular leaf spot and susceptibility to Cercospora leaf spot and Macrophomina. It is indicated for the Brazilian semi-arid region, where angular leaf spot is the main disease of the crop (LIMA et al., 2013).

Prior to sowing, the soil received irrigation sufficient to achieve field capacity, using water according to the treatments. After sowing, irrigation was performed daily at 5 p.m. by applying water to each lysimeter according to the treatment in order to increase soil moisture to field capacity. The applied volume was determined based on the water requirements of the plants, estimated through the water balance: applied volume - volume drained in the previous irrigation.

Sowing consisted of planting 15 seeds of the cultivar CNPA G3 in each lysimeter. Thinning was performed in two steps: when the plants showed two and three pairs of true leaves at 20 and 30 days after sowing (DAS), respectively, leaving the most vigorous plant per plot.

Basal fertilization with $\mathrm{K}$ and $\mathrm{P}$ was based on the recommendation of Novais, Neves and Barros (1991). Calcium nitrate $\left[\mathrm{Ca}\left(\mathrm{NO}_{3}{ }^{-}\right)_{2} \cdot 2 \mathrm{H}_{2} \mathrm{O}\right]$ was used as the source of $\mathrm{NO}_{3}{ }^{-}-\mathrm{N}$, while ammonium chloride $\left(\mathrm{NH}_{4} \mathrm{Cl}\right)$ was used as the source of $\mathrm{NH}_{4}{ }^{+}-\mathrm{N}$. The treatments with proportions of $\mathrm{NO}_{3}{ }^{-} / \mathrm{NH}_{4}{ }^{+}$(PNA) were split; one-third of the recommended dose was applied as a basal amount and the other two-thirds in three equal applications, at intervals of 10 days, with the first one at 25 DAS. In order to inhibit/retard the nitrification of the ammoniacal $\mathrm{N}$ applied to the soil, in each application with ammonium chloride, a nitrification inhibitor (dicyandiamide [DCD]) was used at a dose of $10 \%$ in relation to the total nitrogen $\left(\mathrm{NH}_{4}^{+}\right)$(TRENKEL, 1997). To avoid possible deficiencies of macro- and micronutrients, Ubyfol was applied to the leaves at the beginning of the flowering stage (at 43 DAS) (N [15\%]; $\mathrm{P}_{2} \mathrm{O}_{5}[15 \%]$; $\mathrm{K}_{2} \mathrm{O}$ [15\%]; $\mathrm{Ca}[1 \%] ; \mathrm{Mg}[1.4 \%] ; \mathrm{S}$ [2.7\%]; Zn $[0.5 \%] ;$ B $[0.05 \%] ;$ Fe $[0.5 \%] ; \mathrm{Mn}[0.05 \%] ; \mathrm{Cu}$ $[0.5 \%]$; Mo $[0.02 \%])$.

The emergence of sesame, cultivar CNPA G3, was evaluated through the determination of the percentage of emergence of normal seedlings (EP), emergence speed index (ESI) and growth through plant height (PH), stem diameter (SD) and number of leaves (NL) at 50 and 70 DAS. The production components corresponded to the total number of fruits (TNF), total mass of fruits (TMF), total mass of seeds (TMS) and hull dry mass (HDM).

The EP was obtained by daily counting of the number of emerged plants until establishment, adopting the criterion of the appearance of the epicotyl on the surface of the container. These data were used to determine the ESI via Equation 1, presented by Carvalho and Nakagawa (2000).

$$
\text { ESI (seedlings day } \left.{ }^{-1}\right)=\frac{\sum_{1}}{N_{1}}+\frac{\sum_{2}}{N_{2}} \ldots+\frac{\sum_{n}}{\sum_{n}}
$$

Where: $\sum_{1}, \sum_{2}, \ldots \sum_{\mathrm{n}}-$ number of seedlings emerged in the first, second, ... and last counts; $\mathrm{N}_{1}$, $\mathrm{N}_{2}, \ldots \mathrm{N}_{\mathrm{n}}-$ number of days from the first, second, ... and last counts.

$\mathrm{PH}$ was measured as the distance from the base of the plant to the insertion of the apical meristem, SD was measured at $2 \mathrm{~cm}$ from the base of the plant and NL was obtained through the count of 
each plant. The values of total mass of fruits, seeds and hull were quantified on an analytical scale with a precision of $0.01 \mathrm{~g}$ and the TNF quantified after harvest.

The data were subjected to analysis of variance by a $F$ test. When significant, polynomial regression analysis was applied to the water salinity level factor, and a test of comparison of the means (Tukey at 0.05 probability level) was applied to the proportions of $\mathrm{NO}_{3}{ }^{-}$and $\mathrm{NH}_{4}^{+}$, using the statistical software SISVAR 4.2 (FERREIRA, 2011).

\section{RESULTS AND DISCUSSION}

According to the summary of the analysis of variance by the $\mathrm{F}$ test (Table 2), the interaction between factors $(\mathrm{SL} \times \mathrm{NAP})$ promoted a significant effect $(p<0.01)$ on the variable NL in both evaluated periods. When analyzing the factors separately, the saline levels significantly affected $(\mathrm{p}<0.01)$ the ESI, $\mathrm{EP}, \mathrm{PH}, \mathrm{SD}$ and NL at 50 and 70 DAS. Regarding the proportions of $\mathrm{NO}_{3}{ }^{-}$and $\mathrm{NH}_{4}{ }^{+}$, only $\mathrm{SD}$ at 70 DAS was significantly affected $(\mathrm{p}<0.05)$.

Table 2. Summary of the F test for emergence speed index (ESI), emergence percentage (EP), plant height (PH), stem diameter (SD) and number of leaves (NL) of sesame plants, cultivar CNPA G3, irrigated with saline water and fertilized with different proportions of $\mathrm{NO}_{3}{ }^{-}$and $\mathrm{NH}_{4}{ }^{+}$, at 50 and $70 \mathrm{DAS}$.

\begin{tabular}{|c|c|c|c|c|c|c|c|c|}
\hline \multicolumn{9}{|c|}{ Test $\mathrm{F}$} \\
\hline \multirow{3}{*}{ Source of variation } & \multirow[t]{3}{*}{ ESI } & \multirow[t]{3}{*}{ EP } & \multirow{2}{*}{\multicolumn{2}{|c|}{$\mathrm{PH}$}} & \multirow{2}{*}{\multicolumn{2}{|c|}{$\begin{array}{c}\text { SD } \\
\text { Days after sowing }\end{array}$}} & \multirow{2}{*}{\multicolumn{2}{|c|}{ NL }} \\
\hline & & & & & & & & \\
\hline & & & 50 & 70.45 & 50 & 70 & 50 & 70 \\
\hline Saline levels (SL) & * & ** & $* *$ & $* *$ & $* *$ & $* *$ & $* *$ & $* *$ \\
\hline Linear regression & $*$ & $* *$ & $* *$ & $* *$ & $* *$ & $* *$ & $* *$ & $* *$ \\
\hline Quadratic regression & ns & ns & ns & ns & $*$ & $* *$ & ns & ns \\
\hline Nitrate and ammonium (NAP) & ns & ns & ns & ns & ns & $*$ & ns & ns \\
\hline Interaction (SL x NAP) & ns & ns & ns & ns & ns & ns & $* *$ & $* *$ \\
\hline Blocks & ns & ns & ns & ns & ns & ns & ns & ns \\
\hline CV (\%) & 16.38 & 16.06 & 9.66 & 9.85 & 8.76 & 9.70 & 21.85 & 21.97 \\
\hline
\end{tabular}

$\mathrm{ns}, * *, *$ not significant, significant at $\mathrm{p}<0.01$ and $\mathrm{p}<0.05$, respectively.

The process of germination was evaluated through EP and ESI, and, under saline water irrigation, these variables were significantly affected at the 0.05 and 0.01 probability levels, respectively (Table 2). According to Figure 1, the increase in $\mathrm{ECW}$ linearly reduced the variables, promoting decreases of the order of $4.65 \%$ for ESI and $7.52 \%$

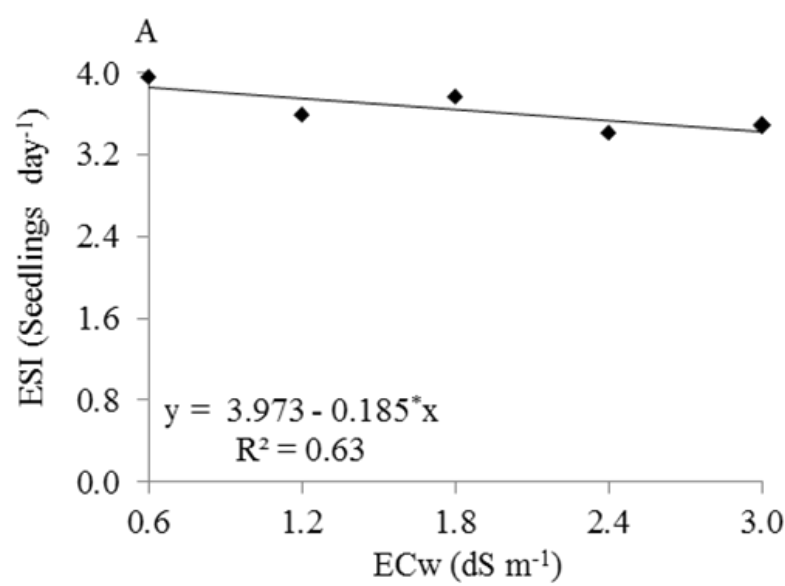

for $\mathrm{EP}$ per unit increase in $\mathrm{ECw}$ (i.e., losses of $11.16 \%$ and $18.05 \%$ in ESI and EP, respectively, between plants irrigated using water of 3.0 and $0.6 \mathrm{dS} \mathrm{m}^{-1}$, respectively, with negative effects on speed index and on the total emergence of normal sesame seedlings).

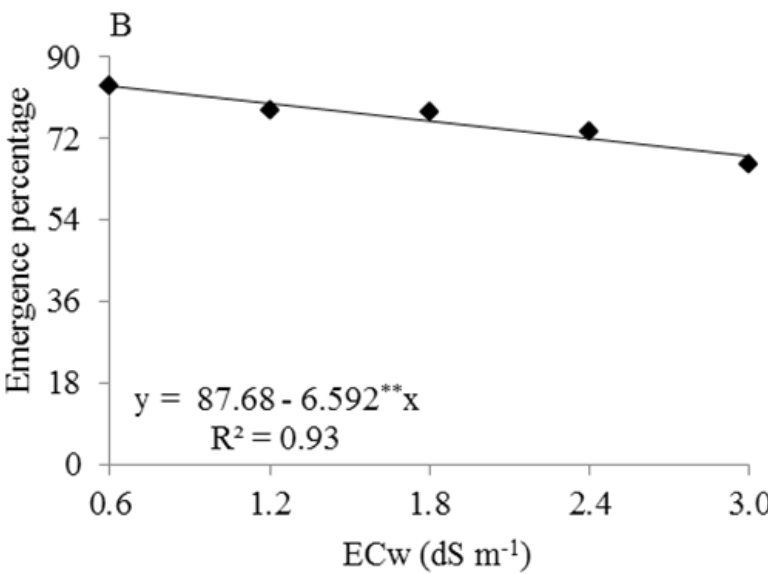

Figure 1. Emergence speed index (ESI) (A) and emergence percentage (EP) (B) of sesame plants, cultivar CNPA G3, as a function of irrigation water salinity $(\mathrm{ECW})$ and fertilization with different proportions of $\mathrm{NO}_{3}^{-}$and $\mathrm{NH}_{4}^{+}$.

When studying the effects of $\mathrm{NaCl}$ on emergence, growth and production of castor bean, Nobre et al. (2013) detected significant effects on ESI and EP, and, as observed in the present study, these variables showed linear decreases of $3.62 \%$ and $3.35 \%$, respectively, per unit increment in $\mathrm{ECW}$. According to Voigt et al. (2009), the reduction of these variables can be attributed to the lower water absorption caused by the increase in the concentration of soluble salts in the soil as well as by the absorption of ions in concentrations sufficient to cause toxicity to the embryo and/or cells of the endosperm membrane. These authors claim that high concentrations of $\mathrm{Na}^{+}$and $\mathrm{Cl}^{-}$ions damage the 
processes of cell division and differentiation; activity of enzymes; and acquisition and distribution of nutrients and may cause delay in seedling emergence and in mobilization of reserves.

As observed in ESI and EP, the concentrations of salts in the irrigation water significantly affected $(\mathrm{p}<0.01) \mathrm{PH}$ and $\mathrm{SD}$ of sesame (Table 2), with linear reductions (Figure 2). The

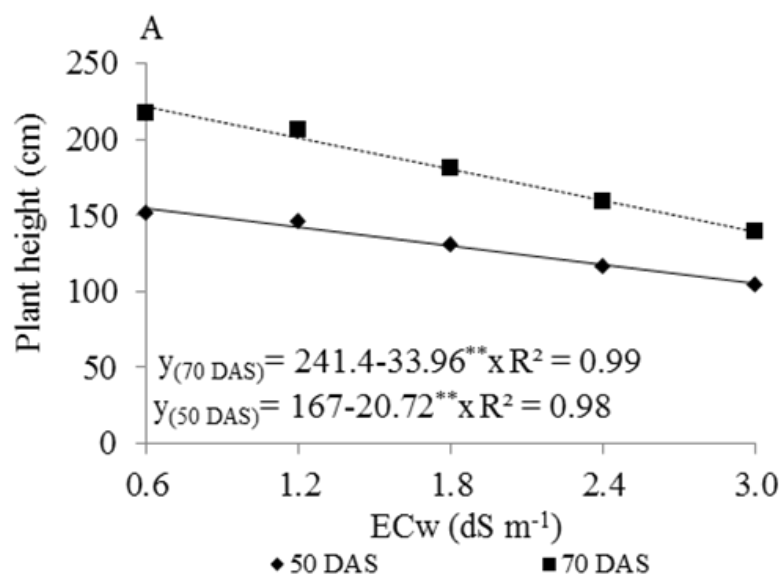

increase in water salinity reduced by $12.41 \%$ and $14.06 \%$ the growth in height of sesame plants per unit increase in $\mathrm{ECw}$, at 50 and 70 DAS, respectively, and the lowest values of $\mathrm{PH}$ were estimated to be 104.82 and $139.58 \mathrm{~cm}$ for plants irrigated with $3.0 \mathrm{dS} \mathrm{m} \mathrm{m}^{-1}$, which represented reductions of $29.78 \%$ and $33.74 \%$, respectively, in both evaluation periods (Figure 2A).

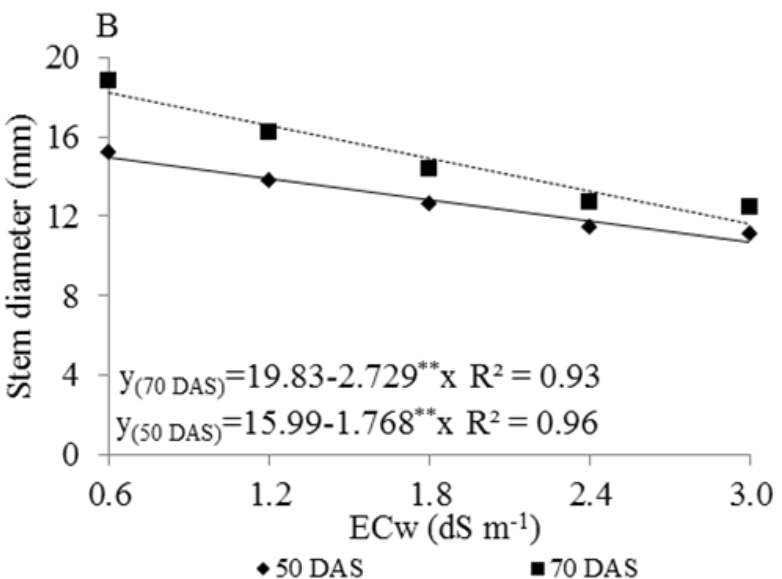

Figure 2. Plant height (PH) (A) and stem diameter (SD) (B) of sesame, cultivar CNPA G3, at 50 and 70 days after sowing (DAS) as a function of irrigation water salinity (ECw).

SD decreased by $11.05 \%$ and $13.76 \%$ per unit increase in $\mathrm{ECw}$, which corresponded to losses of $30.87 \%$ and $38.75 \%$ in the SD of plants irrigated with water of $3.0 \mathrm{dS} \mathrm{m}^{-1}$ compared to the controls, respectively, whose values decreased by 4.24 at 50 DAS and $6.55 \mathrm{~mm}$ at 50 and $70 \mathrm{DAS}$, respectively (Figure 2B). In addition, the stress caused by water salinity on these variables was more intense at 70 DAS, denoting the effect of the accumulation of salts in the soil due to irrigation with saline water over time. According to Nobre et al. (2010), the increase in the concentration of salts in the soil solution, due to the supply from the irrigation water, negatively affects water absorption by plants, due to the reduction in the soil osmotic potential, compromising the photosynthetic and metabolic processes and, consequently, affecting the growth in height and SD.

Based on the values of SD of sesame, cultivar CNPA G3, under different $\mathrm{NO}_{3}{ }^{-} / \mathrm{NH}_{4}{ }^{+}$proportions, there was significant difference between the treatments at 70 DAS (Figure 3) and superiority $(12.29 \%)$ of the plants fertilized only with $\mathrm{NO}_{3}^{-}$ (200/0 mg N kg${ }^{-1}$ of $\left.\mathrm{NO}_{3}{ }^{-} / \mathrm{NH}_{4}{ }^{+}\right)$in comparison to those fertilized only with $\mathrm{NH}_{4}^{+}\left(0 / 200 \mathrm{mg} \mathrm{kg}^{-1}\right.$ of $\mathrm{NO}_{3}{ }^{-} / \mathrm{NH}_{4}{ }^{+}$), while the other proportions did not differ. The excess of $\mathrm{NH}_{4}^{+}-\mathrm{N}$ in the plant tissues, according to Britto and Kronzucker (2005) and Holzschuh et al. (2011), leads to toxicity in the plants because $\mathrm{NH}_{4}{ }^{+}$causes depolarization of the plasma membrane and the tonoplast; acidification of cell organelles in the attempt to maintain the electrical potential of the membranes; changes in the status of carbohydrates of the plants; decoupling of phosphorylation; and, consequently, physiological disorders that lead to the death of the cells and tissue. In studies with interaction of $\mathrm{NO}_{3}{ }^{-}$and $\mathrm{NH}_{4}{ }^{+}$ on the growth of peanut, Ribeiro et al. (2012) did not find significant effects of the treatments on SD, but the authors observed that the best responses occurred for the $\mathrm{NH}_{4}^{+} / \mathrm{NO}_{3}{ }^{-}$ratios of $25 / 75$ and $0 / 100$, respectively. These results demonstrate that the peanut crop responds to the different ratios of the $\mathrm{NH}_{4}{ }^{+}$and $\mathrm{NO}_{3}{ }^{-}$ions in the nutrient solution, and, like sesame, this crop responds better to a supply of $\mathrm{N}$ in the nitric form compared to the ammoniacal form.

The results of the $\mathrm{F}$ test for the data (Table 2) reveal that the interaction between the studied factors (irrigation water salinity and $\mathrm{NO}_{3}{ }^{-} / \mathrm{NH}_{4}{ }^{+}$proportions) significantly influenced at the 0.01 probability level the NL at 50 and 70 DAS, evidencing that the studied factors act interdependently. According to Figures $4 \mathrm{~A}$ and $4 \mathrm{~B}$, there is similar behavior of the variable in the studied periods, such that when sesame plants were subjected to different proportions of $\mathrm{NO}_{3}{ }^{-} / \mathrm{NH}_{4}{ }^{+}$, there were significant differences between the means only in the plants irrigated with water of lower $\left(0.6 \mathrm{dS} \mathrm{m^{-1 } )}\right.$ and higher salinity (2.4 and/or $\left.3.0 \mathrm{dS} \mathrm{m}^{-1}\right)$, at 50 and $70 \mathrm{DAS}$, respectively. 


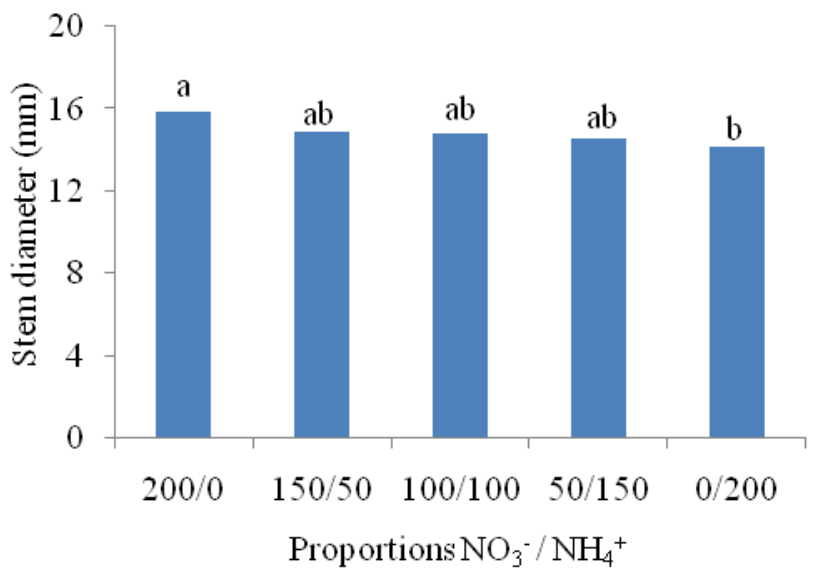

Columns with different letters differ by Tukey test at $\mathrm{p}<0.05$.

Figure 3. Stem diameter (SD) of sesame, cultivar CNPA G3, as a function of fertilization with different proportions of $\mathrm{NO}_{3}{ }^{-}$and $\mathrm{NH}_{4}{ }^{+}$at 70 days after sowing (DAS).
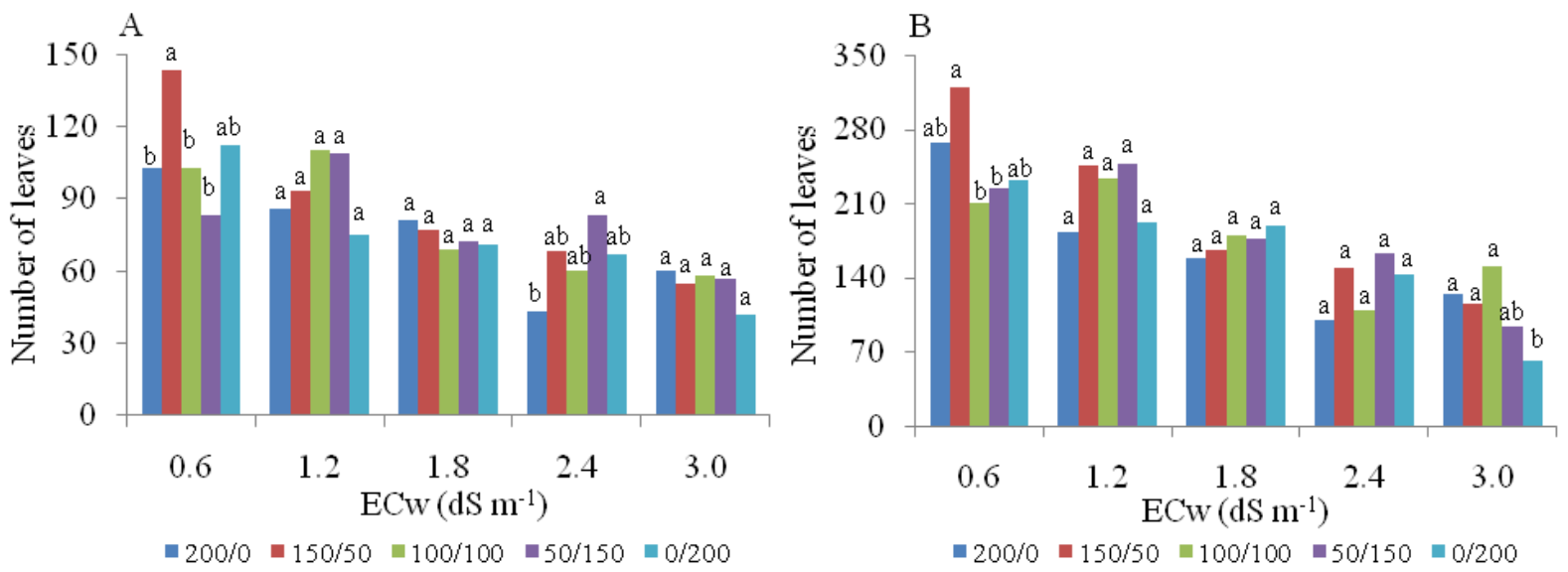

Columns with different letters in the same level of salinity differ by Tukey test at $p<0.05$.

Figure 4. Number of leaves (NL) of sesame, cultivar CNPA G3, at 50 (A) and 70 (B) days after sowing (DAS) as a function of the interaction between irrigation water salinity $(\mathrm{ECW})$ and different proportions of $\mathrm{NO}_{3}{ }^{-}$and $\mathrm{NH}_{4}{ }^{+}$.

According to the tests of comparison of means (Figure 4A and 4B), sesame plants subjected to an ECw of $0.6 \mathrm{dS} \mathrm{m}^{-1}$ and fertilized with an $\mathrm{NO}_{3}{ }^{-}$ $\mathrm{NH}_{4}^{+}$proportion of $150 / 50 \mathrm{mg} \mathrm{kg}{ }^{-1}$ showed the highest NL (143.33 and 319.66 leaves plant ${ }^{-1}$, respectively, at 50 and 70 DAS). Furthermore, the lowest number of leaves (43.33 leaves plant $\left.{ }^{-1}\right)$ occurred at 50 DAS (Figure 4A) in plants irrigated with water of $2.4 \mathrm{dS} \mathrm{m} \mathrm{m}^{-1}$ and subjected to fertilization with $200 / 0 \mathrm{mg} \mathrm{kg}^{-1}$ of $\mathrm{NO}_{3}{ }^{-} / \mathrm{NH}_{4}^{+}$. When comparing the means of the studied treatments (Figure 4B), sesame plants irrigated with water of higher $\mathrm{ECw}$ $\left(3.0 \mathrm{dS} \mathrm{m}^{-1}\right)$ and fertilized with $0 / 200 \mathrm{mg} \mathrm{kg}^{-1}$ of $\mathrm{NO}_{3}{ }^{-}$/ $\mathrm{NH}_{4}^{+}$obtained the lowest NL (61.00 leaves plant $\left.{ }^{-1}\right)$, at 70 DAS. When analyzing the results obtained for NL in both studied periods together (50 and 70 DAS), the crop has greater preference for the absorption of $\mathrm{N}$ in the nitric form. Ribeiro et al. (2012) observed that the use of $\mathrm{NH}_{4}^{+} \mathrm{n}$ greater proportions $(100 / 0$ and $75 / 25$ ) inhibited the production of leaves, and, according to these authors, this effect can be attributed to the fact that the carbohydrates translocated from leaves to roots are preferentially used as skeletons of carbon and energy for the process of $\mathrm{NH}_{4}^{+}$assimilation, to avoid its accumulation to toxic levels, and not for the processes associated with the growth of this organ. Holzschuh et al. (2011) observed, through the analysis of the xylem sap, that $\mathrm{NH}_{4}{ }^{+}$negatively affects the absorption of $\mathrm{K}, \mathrm{Ca}$ and $\mathrm{Mg}$ ions, in magnitudes that depend on their concentrations in the environment.

The interaction between the irrigation water salinity levels and the $\mathrm{NO}_{3}{ }^{-} / \mathrm{NH}_{4}{ }^{+}$proportions significantly affected the mass of fruits and mass of seeds of sesame. On the other hand, the number of fruits harvested and HDM responded to the isolated effects of irrigation water salinity (Table 3). According to the $\mathrm{F}$ test, the production components of the crop respond differently to the effects of the interaction between the studied factors $(\mathrm{SL} \times \mathrm{NAP})$, but all respond to the effects of irrigation water salinity. 
Table 3. Summary of F test results for total number of fruits (TNF), hull dry mass (HDM), total mass of fruits (TMF) and total mass of seeds (TMS) of sesame plants, cultivar CNPA G3, irrigated with saline water and fertilized with different proportions of $\mathrm{NO}_{3}{ }^{-}$and $\mathrm{NH}_{4}{ }^{+}$.

\begin{tabular}{lcccc}
\hline \multirow{2}{*}{ Source of variation } & \multicolumn{4}{c}{ Test F } \\
\cline { 2 - 5 } & TNF & HDM & TMF & TMS \\
\hline Saline levels (SL) & $* *$ & $* *$ & $* *$ & $* *$ \\
Linear regression & $* *$ & $* *$ & $* *$ & $* *$ \\
Quadratic regression & $\mathrm{ns}$ & $\mathrm{ns}$ & $* *$ & $* *$ \\
Nitrate and ammonium (NAP) & $\mathrm{ns}$ & $\mathrm{ns}$ & $*$ & $* *$ \\
Interaction (SL x NAP) & $\mathrm{ns}$ & $\mathrm{ns}$ & $*$ & $*$ \\
Blocks & $\mathrm{ns}$ & $\mathrm{ns}$ & $\mathrm{ns}$ & $\mathrm{ns}$ \\
\hline CV $(\%)$ & 18.37 & 18.30 & 17.64 & 12.87 \\
\hline
\end{tabular}

$\mathrm{ns}, * *, *$ not significant, significant at $\mathrm{p}<0.01$ and $\mathrm{p}<0.05$, respectively.

The total number of fruits per plant of sesame decreased linearly with an increase in ECw, showing a reduction of $31.45 \%$ in the number of fruits per unit increase in $\mathrm{ECW}$ (Figure 5A). When analyzing the behavior of this phenomenon, there was a reduction of $93.79 \%$ (106.74 fruits plant $\left.{ }^{-1}\right)$ between

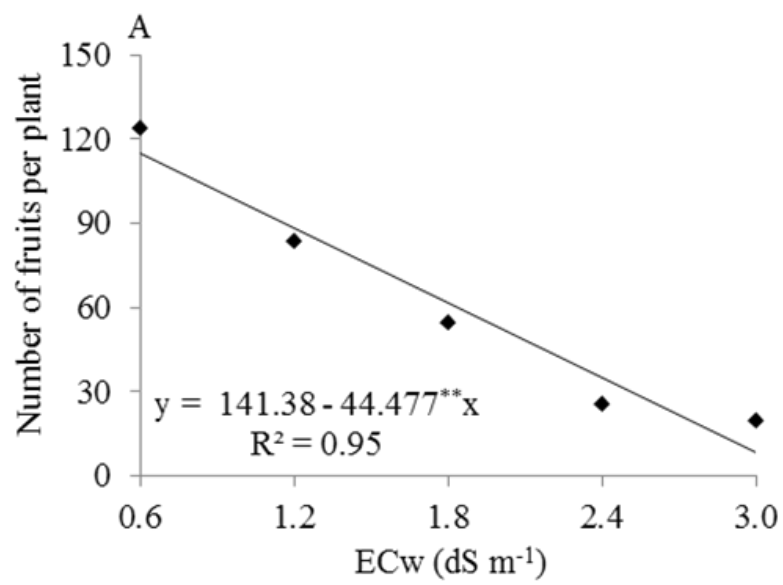

Figure 5. Number of fruits per plant (A) and hull dry mass irrigation water salinity.

As observed for TNF, HDM also decreased linearly with an increase in saline water level, showing a reduction of $32.22 \%$ per unit increase of $\mathrm{ECW}$ in the studied interval. Santos et al. (2012) claimed that this trend could be attributed to the fact that the plant, in order to adjust osmotically, uses a certain amount of energy for the accumulation of sugars, organic acids and ions in the vacuole, and this energy could be used for growth and production. Nobre et al. (2013) reported that the stresses caused by excess ions, in general, reduce $\mathrm{CO}_{2}$ assimilation, stomatal conductance, transpiration and photosynthesis and, consequently, reduce crop production.

The interaction between the studied factors (irrigation water salinity and $\mathrm{NO}_{3}{ }^{-} / \mathrm{NH}_{4}{ }^{+}$proportions) the highest $\left(\mathrm{ECW}=3.0 \mathrm{dS} \mathrm{m}^{-1}\right)$ and lowest $\left(\mathrm{ECW}=0.6 \mathrm{dS} \mathrm{m} \mathrm{m}^{-1}\right)$ levels of irrigation water salinity, and it can be concluded that the increase in water salinity directly interferes with the number of fruits and, consequently, the mass of seeds.

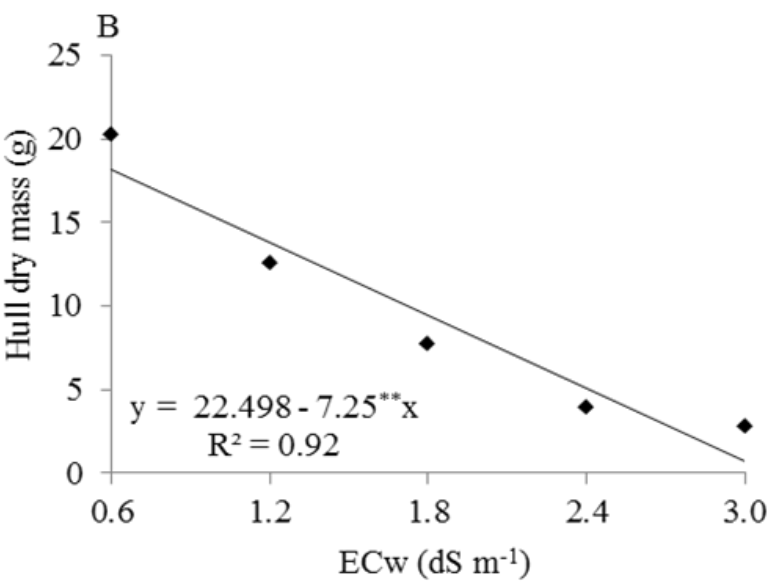

significantly influenced, at the 0.01 probability level, the masses of fruits and seeds, reinforcing the fact that the studied factors do not act only in isolation on these variables. According to Figure 6A and 6B, there is a similar behavior of these variables, such that when the sesame plants were subjected to different proportions of $\mathrm{NO}_{3}{ }^{-} / \mathrm{NH}_{4}{ }^{+}$, a significant difference occurred only when the plants were irrigated with water of lower salinity (0.6 and $\left.1.2 \mathrm{dS} \mathrm{m}^{-1}\right)$. On the other hand, when the plants were subjected to irrigation with water of $1.8,2.4$ and $3.0 \mathrm{dS} \mathrm{m}^{-1}$, regardless of the $\mathrm{NO}_{3}{ }^{-} / \mathrm{NH}_{4}{ }^{+}$ proportion, there was no significant effect $(\mathrm{p}>0.05)$ of this interaction on the TMF or TMS variable. 

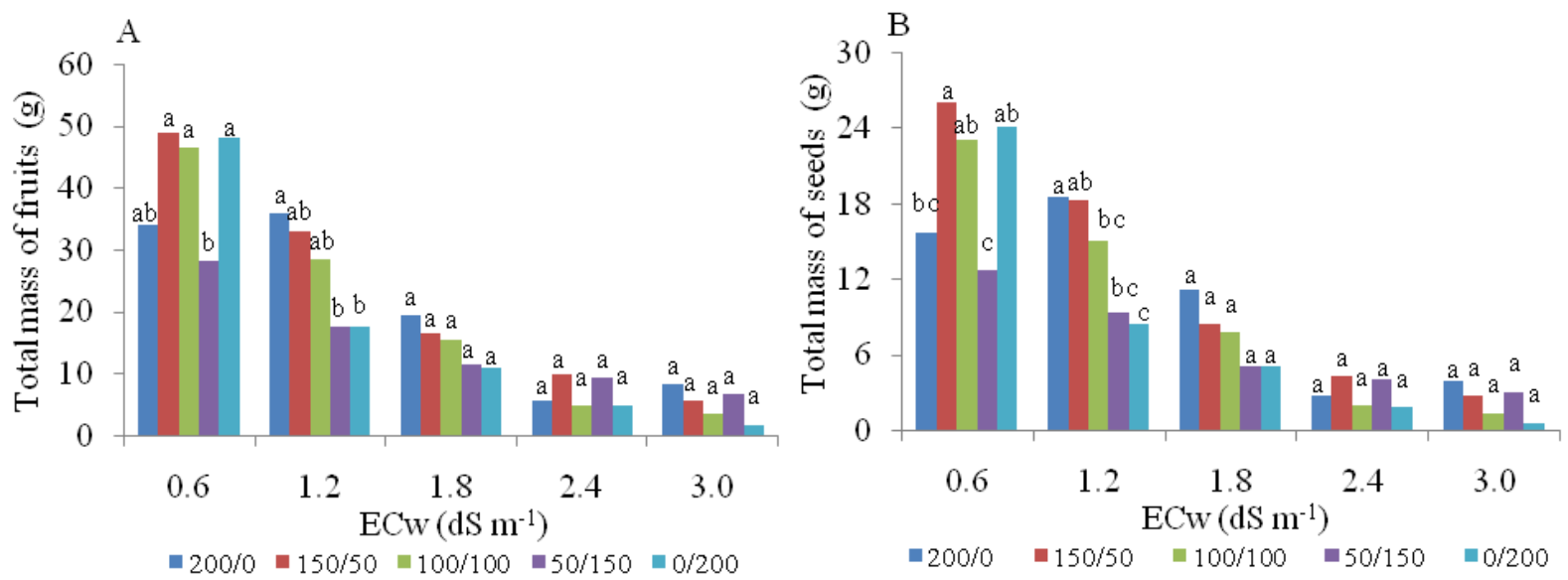

Columns with different letters in the same level of salinity differ by Tukey test at $\mathrm{p}<0.05$.

Figure 6. Total mass of fruits (TMF) (A) and total mass of seeds (TMS) (B) of sesame, cultivar CNPA G3, as a function of the interaction between irrigation water salinity and different proportions of $\mathrm{NO}_{3}{ }^{-}$and $\mathrm{NH}_{4}{ }^{+}$.

As observed in the results for NL (Figure 4A and $4 \mathrm{~B})$, the highest values of total masses of fruits and seeds (48.84 and $26.04 \mathrm{~g}$ ) were obtained in sesame plants irrigated with an $\mathrm{ECw}$ level of $0.6 \mathrm{dS} \mathrm{m}^{-1}$ and fertilized with an $\mathrm{NO}_{3}{ }^{-1} \mathrm{NH}_{4}{ }^{+}$ratio of $150 / 50$. On the other hand, although there was no significant influence on the total masses of fruits and seeds, plants subjected to an ECW of $3.0 \mathrm{dS} \mathrm{m}^{-1}$ and fertilized using proportions with larger amounts of ammonium chloride obtained the lowest TMF and TMS (1.69 and $0.55 \mathrm{~g}$ ). According to the results, as the $\mathrm{ECW}$ levels increased, the dose of $\mathrm{NH}_{4}{ }^{+}$above the $100 / 100$ ratio $\left(\mathrm{NO}_{3}{ }^{-} / \mathrm{NH}_{4}{ }^{+}\right)$intensified the deleterious effects on plant production, indicating that the sesame crop absorbs more $\mathrm{N}$ in the form of $\mathrm{NO}_{3}{ }^{-}$. In a study with peanut plants, Ribeiro et al. (2012) also found a reduction in the development of this crop, which resulted in damage to its production, when the crop was subjected to higher proportions of $\mathrm{NH}_{4}^{+}\left(100 / 0\right.$ and $75 / 25$ of $\left.\mathrm{NH}_{4}^{+} / \mathrm{NO}_{3}{ }^{-}\right)$. This reduction was attributed to restrictions in the water flow of the plant, due to the effects of salinity caused by the $\mathrm{NH}_{4}{ }^{+}$ion, which promotes a reduction in the activity of the nitrate reductase enzyme, according to Silva et al. (2011). These authors claim that the effects of $\mathrm{NH}_{4}^{+}$toxicity are attributed to the reduction or inhibition of the absorption of cations, especially $\mathrm{K}$, as a consequence of the imbalance of ions.

When analyzing the effects of different proportions of $\mathrm{NO}_{3}{ }^{-} / \mathrm{NH}_{4}{ }^{+}$on cotton, cultivar BRS Topaz, under saline stress, Lima et al. (2016) found that fertilization with a higher $\mathrm{NO}_{3}{ }^{-}$dose $(75 / 25 \mathrm{mg}$ of $\mathrm{NO}_{3} \mathrm{~N} / \mathrm{NH}_{4}{ }^{+}-\mathrm{N}$ ) promoted lower production of cotton seed mass (5.64 g plant $\left.^{-1}\right)$, but when the plants were subjected to the proportions of $25 / 75$ and $0 / 100$ (mg of $\mathrm{NO}_{3} \mathrm{~N} / \mathrm{NH}_{4}{ }^{+} \mathrm{N}$ ), they obtained the highest values of cotton seed mass (26.53 and 27.94 g plant $^{-1}$, respectively). Araújo et al. (2012) also found the largest numbers of panicles per plant in two rice cultivars when the proportion of the forms of $\mathrm{N}$ was $75 \% \mathrm{NO}_{3}^{-}$and $25 \% \mathrm{NH}_{4}^{+}$, and maximum grain production was observed when the ratio was equal to $78 \%$ and $77 \%$ for the cultivars BRS Colosso and BRSMG Conai, respectively.

\section{CONCLUSIONS}

The increase in irrigation water salinity compromises the emergence, growth and production of sesame, cultivar CNPA G3, and the production components are the variables most sensitive to saline stress.

The greatest growth of sesame, cultivar CNPA G3, evaluated by SD is obtained when plants are fertilized with a $\mathrm{NO}_{3}{ }^{-} / \mathrm{NH}_{4}{ }^{+}$ratio of 200/0 $\mathrm{mg} \mathrm{kg}^{-1}$.

An ECw level of $3.0 \mathrm{dS} \mathrm{m}^{-1}$ and fertilization with $0 / 200 \mathrm{mg} \mathrm{kg}$ of $\mathrm{NO}_{3}^{-} / \mathrm{NH}_{4}^{+}$promotes deleterious effects on the TMF and mass of seeds in the sesame crop.

The interaction between saline water levels and $\mathrm{NO}_{3}{ }^{-} / \mathrm{NH}_{4}{ }^{+}$proportions significantly affects the NL (at 50 and 70 DAS), the TMF and the mass of seeds.

\section{ACKNOWLEDGMENTS}

We are grateful to the National Post-Doctorate Program (PNPD/CAPES/UFCG) for grant of scholarship to the second author and to the National Institute of Science and Technology in Salinity (INCTSal) for funding the project.

\section{REFERENCES}

ABBASDOKHT, H. et al. Effects of different salt levels on germination and seedling growth of sesame (Sesamum indicum L.) cultivars. Technical Journal of Engineering and Applied Sciences, Montreal, v. 
2, n. 10, p.309-313, 2012 .

ALI, A.; SIVAKAMI, S.; RAGHURAM, N. Effect of nitrate, nitrite, glutamate, glutamine and 2-oxoglutarate on RNA, levels and enzyme activities of nitrate reductase and nitrite reductase in rice. Physiology and Molecular Biology of Plants, Heidelberg, v. 13, n. 1, p. 17-25, 2007.

ALVES, M. S. et al. Estratégias de uso de água salobra na produção de alface em hidroponia NFT. Revista Brasileira de Engenharia Agrícola e Ambiental, Campina Grande, v. 15, n. 5, p. 491-498, 2011.

AMABILE, R. F. et al. CNPA G3: Nova opção de gergelim para a região do Distrito Federal. 1. ed. Planaltina: EMBRAPA Cerrados, 2001. 3 p. (Comunicado Técnico, 43).

ARAÚJO, A. C. D. et al. Análise não destrutiva de crescimento do gergelim consorciado com feijão caupi em sistema orgânico de cultivo. Revista Brasileira de Agroecologia, Pelotas, v. 9, n.1, p. 259-268, 2014.

ARAÚJO, J. L. Crescimento e produção do arroz sob diferentes proporções de nitrato e de amônio. Revista Brasileira de Ciência do Solo, Viçosa, v. 36, n. 3, p. 921-930, 2012.

BAHRAMI H.; RAZMJOO J. Effect of salinity stress $(\mathrm{NaCl})$ on germination and early seedling growth of ten sesame cultivars (Sesamum indicum L.). International Journal of AgriScience, Dubendorf, v. 2, n. 6, p. 529-537, 2012.

BRITTO, D. T.; KRONZUCKER, H. J. Plant nitrogen transport and its regulation in changing soil environments. Journal of Crop Improvement, Kansas, v. 15, n. 2, p. 1-23, 2005.

CARVALHO, N. M.; NAKAGAWA, J. Sementes: Ciência, tecnologia e produção. 4. ed. Jaboticabal: FUNEP, 2000, 588 p.

DONAGEMA, G. K. et al. Manual de métodos de análise de solo. 2. ed. Rio de Janeiro, RJ: Embrapa Solos. 2011. 230 p.

FERREIRA, D. F. Sisvar: A computer statistical analysis system. Revista Ciência e Agrotecnologia, Lavras, v. 35, n. 6, p. 1039-1042. 2011.

FLOWERS, T. J. Improving crop salt tolerance. Journal of Experimental Botany, Oxford, v. 55, n. 396, p. 307-319, 2004.

GARCIA, G. O. et al. Respostas de genótipos de feijoeiro à salinidade. Engenharia na Agricultura,
Viçosa, v. 18 , n. 4, p. $330-338,2010$

HACHIYA, T. et al. Nitrate addition alleviates ammonium toxicity without lessening ammonium accumulation, organic acid depletion and inorganic cation depletion in Arabidopsis thaliana shoots. Plant and Cell Physiology, Oxford, v. 53, n. 3, p. 577-591, 2012.

HOLZSCHUH, M. J. et al. Absorção de nutrientes e crescimento do arroz com suprimento combinado de amônio e nitrato. Revista Brasileira de Ciência do Solo, Viçosa, v. 35, n. 4, p. 1357-1366, 2011.

LIMA, G. S. et al. Cultivation of colored cotton irrigated with saline water under potassium and nitrate/ammonium fertilization. African Journal of Agricultural Research, Lagos, v. 11, n. 1, p. 32-39, 2016.

LIMA, G. S. et al. Produção da mamoneira cultivada com águas salinas e doses de nitrogênio. Revista Ciência Agronômica, Fortaleza, v. 46, n. 1, p. 1-10, 2015.

LIMA, G. S. et al. Utilização de águas salinas e doses de adubação nitrogenada no cultivo da mamoneira cv. BRS Energia. Revista Verde de Agroecologia e Desenvolvimento Sustentável, Mossoró, v. 7, n. 2, p. 88-95, 2012.

LIMA, M. S. R. et al. Produção de sementes de gergelim In: BELTRÃO, N. E. M. et al. (Eds.). O gergelim e seu cultivo no semiárido brasileiro. Natal: IFRN, 2013, cap. 6, p. 85-101.

MASCLAUX-DAUBRESSE, C. et al. Nitrogen uptake, assimilation and remobilization in plants: Challenges for sustainable and productive agriculture. Annals of Botany, London, v. 105, n. 1, p. 1141-1157, 2010.

NOBRE, R. G. et al. Crescimento e floração do girassol sob estresse salino e adubação nitrogenada. Revista Ciência Agronômica, Fortaleza, v. 41, n. 3, p. 358-365, 2010.

NOBRE, R. G. et al. Emergência, crescimento e produção da mamoneira sob estresse salino e adubação nitrogenada. Revista Ciência Agronômica, Fortaleza, v. 44, n. 1, p. 76-85, 2013.

NOVAIS, R. F.; NEVES, J. C. L.; BARROS, N. F. Ensaio em ambiente controlado. In: OLIVEIRA, A. J. et al. (Ed.). Métodos de pesquisa em fertilidadedo solo. Brasília: Embrapa SEA, 1991. p. 189-253.

RHOADES, J. D.; KANDIAH, A.; MASHALI,A. $M$. Uso de águas salinas para produção agrícola. 
1. ed. Campina Grande: UFPB. 2000. 117 p. (Estudos da FAO. Irrigação e Drenagem).

RIBEIRO, M. O. et al. Efeito das interações entre os íons amônio e nitrato na fisiologia do crescimento do amendoinzeiro. Revista Ceres, Viçosa, v. 59, n. 5, p. 630-635, 2012.

SANTOS, D. B. et al. Produção e parâmetros fisiológicos do amendoim em função do estresse salino. Revista Idesia, Arica, v. 30, n. 2, p. 69-74, 2012.

SILVA, S. M. et al. Atividade da enzima nitrato redutase em milho cultivado sob diferentes níveis de adubação nitrogenada e potássica. Revista Ciência Rural, Santa Maria, v. 41, n. 11, p. 1931-1937, 2011.

SOUSA, G. G. et al. Lâminas de irrigação para cultura do gergelim com biofertilizante bovino. Revista Magistra, Cruz das Almas, v. 26, n. 3, p. 347-356, 2014.

SUASSUNA, J. F. Tolerância de genótipos de gergelim ao estresse salino. 2013. 126 f. Tese (Doutorado em Engenharia Agrícola: Área de Concentração em Irrigação e Drenagem) Universidade Federal de Campina Grande, Campina Grande, 2013.

TAIZ, L.; ZEIGER, E. Fisiologia vegetal. 5. ed. Porto Alegre, RS: Artmed. 2013. 954 p.

TRENKEL, M. E. Improving fertilizer use efficiency: Controlled-release and stabilized fertilizers in agriculture. Paris: IFIA, $1997.151 \mathrm{p}$.

VOIGT, E. L. et al. Source-sink regulation of cotyledonary reserve mobilization during cashew (Anacardium occidentale) seedling establishment under $\mathrm{NaCl}$ salinity. Journal of Plant Physiology, Stuttgart, v. 166, n. 1, p. 80-89, 2009. 